Джабаева Т.Ч. Влияние общероссийских политических процессов на судебную систему в Дагестане во второй половине XIX - начале XX в.

УДК 94(470.67) «18/19»:34

DOI: $10.21779 / 2542-0313-2016-31-4-32-36$

\title{
Т.Ч. Джнабаева
}

\section{Влияние общероссийских политических процессов на судебную систему в Дагестане во второй половине XIX - начале XX в.}

Дагестанский государственный университет; Россия, 367001, 2. Махачкала, ул. М. Гаджиева, 43a; tahmina.dj@rambler.ru

Статья посвящена исследованию вопросов, связанных с правовыми реформами в Дагестане во второй половине XIX - начале XX в. Особое внимание уделено месту, значению и соотношению обычного права и шариата в судебной системе данного периода. В ней также рассматриваются проблемы государственно-политического устройства Дагестана в составе России, влияния внутрироссийских реформ на социально-правовую систему Дагестана второй половины XIX - начала XX в.

Царское правительство решило, исходя из своих колониальных интересов и задач, ввести во всем Дагестане судопроизводство, основанное главным образом на адате и частично на шариате, с соблюдением трех непременных условий: подчиненность и подотчетность судебных органов военной администрации, охранение интересов государства и социальной верхушки и исключение из судопроизводства наиболее консервативных норм. После революции 1917 года и усиления социальной роли духовенства значение суда по шариату возросло в отличие от суда по обычному праву. Однако вскоре в силу внутриполитических факторов как судопроизводство, так и духовенство в целом было взято под жесткий контроль государства.

Ключевые слова: Дагестан, судопроизводство, судебная реформа, шариат, обычное право (адат), иарская администрачия, революиия, мусульманское духовенство, Советская власть.

Во второй половине XIX в. под влиянием реформирования судебной системы в Российской империи, целью и результатом которой явился переход от сословного суда к бессословному и гласному, устанавливались независимость суда от администрации, несменяемость судей и состязательность процесса, а также публикация новых уставов уголовного и гражданского судопроизводства. Преобразования коснулись и судебной системы северокавказских народов, однако цели здесь преследовались иные. Российским властям необходимо было, ослабив роль шариата и приспособив адатное (обычное) право к российской правовой системе, осуществить переход к единому законодательству, к единому судопроизводству и к единой судебной системе. Реформирование судебной системы не только позволяло изменить порядок принятия решений, но и являлось ощутимым социальным внушением для населения, демонстрирующим новое время и новые социально-экономические реалии.

В качестве руководящего принципа при составлении проекта кавказской судебной реформы признавалась необходимость согласования основных положений общероссийского законодательства с нормами адата и шариата в целях постепенного распространения на край законов империи.

Прежде всего российская администрация на Северном Кавказе ввела окружные суды, которые позже были заменены на горские словесные. Иногда для их обозначения применялся термин «народные суды». Статус и сущность горских словесных и народных судов были закреплены в ст. 761 Устава гражданского судопроизводства (1864) и в 
Джабаева Т.Ч. Влияние общероссийских политических процессов на судебную систему в Дагестане во второй половине XIX - начале XX в.

ст. 220 «Учреждения управления Кавказского края» в редакции 1906 г., где отмечалось, что «горские суды сохраняются временно, в зависимости от успеха гражданственности» [1, с. 87].

Опубликованные судебные уставы от 20 ноября 1864 г. для Кавказского края в целом и для Дагестана в частности допускали в распространение их действия на местах с некоторыми отступлениями от общероссийского порядка судоустройства и судопроизводства, обусловленными местными особенностями. Царское правительство решило, исходя из своих колониальных интересов и задач, ввести во всем Дагестане судопроизводство, основанное главным образом на адате и частично на шариате, с соблюдением трех непременных условий: подчиненность и подотчетность судебных органов военной администрации, охранение интересов государства и социальной верхушки и исключение из судопроизводства наиболее консервативных норм. Поэтому царская администрация провела работу по сбору и постепенной унификации адатов сельских общин и вольных обществ Дагестана. Эта работа была начата еще раньше, в 20-х годах XIX в., и прекратилась в связи с военными событиями на Кавказе [2, с. 37].

Апелляционной инстанцией для сельских судов был окружной суд, а для последнего - Дагестанский народный суд, который состоял из председателя (назначенного командующим войсками области с утверждением главнокомандующего Кавказской армии), членов суда (выходцев из социальной верхушки) и кадия. Председателем окружного суда был начальник округа или его заместитель. Сельский суд состоял из судьи (судей), его (их) помощников и кадия. Таким образом, дела решались на основании местных обычаев, и только по таким делам, для решения которых обычай не сложился, суд руководствовался общими законами империи. По шариату разбирались дела о заключении и расторжении брака, о личных и имущественных правах, вытекающих из брака, о законности рождения и дела о наследстве.

При рассмотрении дел, подлежащих разрешению на основании норм шариата, в заседании суда участвовал кадий, который перед вынесением решения представлял свое мнение. Все бракоразводные дела кадий рассматривал единолично. Рассмотрение шло «изустно и публично», закрытое рассмотрение допускалось по делам «о проступках против прав семейственных, об оскорблении женской чести и других, соединенных с соблазном действиях, а также дела о проступках, преследуемых не иначе, как по жалобам частных лиц» [3, с. 28].

Учитывая соотношение рассмотренных дел суда по адату, шариату и официального суда, отметим, что обращения в официальные судебные органы имели наименьший процент, так как сопровождались определенными идеологическими трудностями. Обращение в официальный суд у большинства горцев считалось едва ли не постыдным делом, и предпочтение отдавалось «почетным старикам», общинному собранию, которые назначали предусмотренное адатами наказание.

Значительное место в деятельности судов по адату отводилось делам о воровстве, поранении, драке и т. д. Существуют своды адатов различных обществ, где детально изложены те или иные наказания за преступления. Основной формой наказания правонарушителя были имущественные и денежные штрафы.

Одновременное функционирование различных систем судов в общественной жизни горцев свидетельствует о живучести патриархальных пережитков, переплетавшихся с элементами феодальных отношений, о влиянии ислама и наличии общинных традиций коллективизма. 
Джабаева Т.Ч. Влияние общероссийских политических процессов на судебную систему в Дагестане во второй половине XIX - начале XX в.

Проводя судебно-административные реформы, царское правительство не до конца доверяло сельскому суду и членам управления, строго следило за их деятельностью и держало их под контролем. Приняв во внимание традиционную гибкость адата, новая администрация умело использовала это его качество. Допуская применение норм адата, царизм предоставил кавказской администрации самые широкие полномочия по ограничению и изменению обычно-правовых норм в соответствии с интересами колониальной политики. Постепенно такая политика властей стала давать свои плоды. Горское население все больше вовлекалось в правовое пространство России, знакомилось с законодательством империи и училось его применять.

Государство в данный исторический период, не всегда применяя допустимые средства и методы, неоднократно активно вторгалось в сферу религиозной деятельности духовенства, пыталось вытеснить религиозные объединения в частную сферу [4, с. 102], лишить их политических притязаний, подчинить религиозные структуры или четко определить рамки их деятельности [5, с. 73], тем самым отстаивая интересы государства и справедливо преследуя и добиваясь определенных внутриполитических целей [6, с. 93]. Тем не менее идеологическая сфера дореволюционного Дагестана испытывала на себе определенное влияние религии, и особенно оно проявлялось в области судопроизводства.

Однако после революционных событий в Дагестане в начале 1917 года духовенство, наряду с местной буржуазией, интеллигенцией и беками, стало наиболее влиятельной силой и весьма активно включилось в политическую борьбу. Все это отражало расстановку политических сил в области.

В начале апреля 1917 года в Темир-Хан-Шуре было образовано общество исламистов (Джамиат-уль-Исламие), на основе которого в июле был создан Дагестанский областной мусульманский национальный комитет (Милли-комитет), который в своей деятельности руководствовался идеями и пожеланиями дагестанского духовенства.

Так, в рабочем режиме в Темир-Хан-Шуре был созван съезд алимов. На съезде был поднят вопрос о введении шариата вместо адатов и действовавших до того момента государственных судебных законов.

В начале работы съезда представителями были разъяснены основы мировой религии «Ислам», ее особенности в отличие от других религий, ее теоретическая составляющая и практическое воплощение в виде исламской этики и правовых норм мусульманской религии. Кроме того, были приведены основы шариата, одна из которых базировалась на идее равенства права, а не на физическом или духовном равенстве. Иными словами, невозможно найти внешне и внутренне одинаковых людей, поэтому, необходимо взаимное обеспечение интересов всех по праву. «Выдвигаемые революцией демократические идеи во имя прав человека, - отмечалось в докладе, - глубоко и органически присущи исламу» [7, л. 3].

Представители съезда отметили, что задачами ислама также являются улаживание споров, искоренение вражды и справедливое нормирование жизни, и в современных реалиях необходимо сконцентрироваться не на духовных ритуалах, а на справедливом разрешении противоречивых интересов общества. Поэтому религиозная секция съезда не ограничивается организацией духовного управления и обучения, а берет на себя функцию юридического органа, решающего вопросы судоустройства и судопроизводства. Была дана инструкция для работы судов по шариату, перечислены требования к судье, членам суда, указаны возрастной ценз, участие женщин и т. д., отмечены общие 
Джабаева Т.Ч. Влияние общероссийских политических процессов на судебную систему в Дагестане во второй половине XIX - начале XX в.

черты адата и шариата. Соответственно с введением последнего, уменьшалось значение суда по адату.

В итоге съезд единогласно вынес постановление ввести суд по шариату. Участник съезда М.К. Дибиров пишет, что «для однообразности решения во всех судах было решено иметь определенную книгу - свод шариатских законов. Составление этой шариатской книги поручили особой комиссии из ученых алимов. Эта книга должна была быть составлена на принципе беспристрастности и справедливости ко всем верованиям и партиям, адаптируясь к духу времени» и приспосабливаясь к жизненным интересам каждой народности, но с условием ненарушения шариата в его основах и соблюдения пожертвований [8]. Усиливающееся влияние духовенства в регионе обнаружилось на втором съезде горцев Северного Кавказа и Дагестана, на котором был избран имамом мусульман Дагестана и Северного Кавказа Нажмудин Гоцинский.

В первые годы советской власти руководство республики пыталось учесть особенности и менталитет горцев. Подобное отношение было продиктовано не только желанием избежать конфронтации с населением, но и заявлениями крупных советских руководителей о признании шариата и адатов религиозными и национальными особенностями мусульман.

Тем не менее, несмотря на заявления и обещания властей, религиозная деятельность духовенства по всей стране была поставлена под жесткий контроль [9, с. 54]. Со временем подконтрольные государству данные процессы в целом были дагестанским обществом как факт. На социально-экономическое и правовое положение мусульманского духовенства повлияли антирелигиозные меры Советского государства, которые имели наступательный и необратимый характер [10, с. 96]. Однако и в тех исторических условиях имели место многочисленные компромиссы, как со стороны государства, так и со стороны духовенства Дагестана.

\section{Литература}

1. Абазов A.X. Нальчикский округ в судебной системе Терской области (последняя треть XIX - начало XX в.). - Нальчик: Издательский отдел КБИГИ, 2014. - 108 с.

2. Мусаева А.Г. Правовые реформы в дагестане во второй половине XIX века // Coвременные проблемы науки и образования. - 2015. - № 1-1.

3. Рейнеке Н.М. Горские народные судьи Кавказского края. - СПб., 1912.

4. Сулаев И.Х. Официальное мусульманское духовенство в Советском Дагестане // Вопросы истории. - 2006. - № 12; Он же. Общественно полезная деятельность Духовного управления мусульман Северного Кавказа хорошо известна уполномоченному Совета... / Документы ГАРФ и ЦГА Республики Дагестан о взаимоотношениях институтов государства и ислама второй половины XX в. // Отечественные архивы. - 2006. № 2 .

5. Гичибекова Р.М., Омаров А.И. Из истории политики самодержавия в отношении мусульманского мира Кавказа в первой трети XIX века // Вестник Дагестанского государственного университета. - 2014. - Вып. 4.

6. Джабаева Т.Ч. Социальная роль мусульманского духовенства в обществе Дагестана в XIX в. // Вестник Дагестанского государственного университета. - 2013. Вып. 4.

7. Основные положения о мусульманской религии к докладу духовной секции на буржуазно-националистическом съезде племен Северного Кавказа и Дагестана // ЦГА РД. Ф. p-614. Оп. 1. Д. 1. 
Джабаева Т.Ч. Влияние общероссийских политических процессов на судебную систему в Дагестане во второй половине XIX - начале XX в.

8. Разаков Р.Ч.-М. Мусульманское духовенство в борьбе за власть в Дагестане // alpan365.ru.

9. Сулаев И.Х. Государственная политика государства в области мусульманского образования (первая треть XX в.). Историко-правовой аспект // Исламоведение. - 2013. - № 2. - С. 50-54.

10. Сулаев И.Х. Социально-экономическое и правовое положение мусульманского духовенства в Советском Дагестане (20-30-е гг.) // Вестник Института ИАЭ. - 2008. № 4. - С. 87-98.

Поступила в редакцию 29 сентября 2016 г.

UDC 94(470.67) «18/19»:34

DOI: $10.21779 / 2542-0313-2016-31-4-32-36$

\section{The influence of Russian political process on the legal system of Dagestan in the $2^{\text {nd }}$ half of XIX - early XX}

\section{T.Ch. Dzhabayeva}

Dagestan State University; Russia, 367001, Makhachkala, M. Gadzhiyev st., 43a; tahmina.dj@rambler.ru

The article is devoted to issues related to legal reforms in Dagestan in the second half of XIX early XX centuries - places, values and correlation of the customary law and Sharia in the judicial system of this period. The article involves the study of the complex issues related to state and political structure of Dagestan in Russia, the impact of domestic reforms on the socio-legal system of Dagestan in the second half of XIX - early XX centuries

The Russian tsarist government on the assumption of its colonial interests and objectives introduced a specific legal system in Dagestan. It was based on the Adats mainly and Sharia partially and required three obligatory conditions: subordination and accountability of the judicial authorities of military administration safeguard the interests of the state and social elite and the exclusion of the most conservative standards from the procedure. After the 1917 revolution and the increasing of the clergy's social role the significance of Sharia law increased in contrast to customary law. Soon, however, due to the internal political factors both the judiciary and the clergy were taken under strict state control.

Keywords: Dagestan, judicial proceedings, judicial reform, Sharia, customary law (ADAT), Imperial administration, revolution, Muslim clergy, Soviet government.

Received 29 September, 2016 